\title{
Impediments of Reaching God and Ways of Surmounting Them in Two Selected Allegories of Rumi's Spiritual Couplets
}

\author{
Ahmad Gholi (corresponding author) \\ English Department, Faculty of Humanities, Gonbad Kavous University, Golestan Province, Iran \\ Masoud Ahmadi Mosaabad \\ English Department, Faculty of Humanities, Gonbad Kavous University, Golestan Province, Iran
}

\begin{abstract}
Rumi frequently utilizes allegories in the grand architecture of his six-book Masnavi-ye Manavi to explain the complex philosophical and religious issues refreshingly, give aesthetic dimension to otherwise cold subjects artistically, and teach morals delightfully. Like his predecessors, he also picks up the ancient old motif of spiritual journey in some of his allegories to depict the problems of the seeker on his path towards God. The present study is undertaken to shed light on the wayfarers' barriers and the ways of surmounting them in two selected allegories from Masnavi.
\end{abstract}

Index Terms—allegory, journey, seeker, path, barriers, surmounting

\section{INTRODUCTION}

From the time Islam became an established religion in Persia in $7^{\text {th }}$ century, most Persian poets and scholars particularly in medieval times devoted their intellectual and literary energies on the ideals of Islam. One of those eminent poets is Rumi (1207-1273) who achieved this goal through composing Masnavi-ye Manavi or Spiritual Couplets, consisted of 25700 rhyming couplets in six books. Jami, classical Persian poet, considers it as "the interpretation of Qur'an in Persian" (qtd in Emerick, p.18, 2008) because Rumi extensively and heavily got his inspiration and materials from Qur'an. In fact, Rumi in his masterpiece built an eternal- sumptuous palace whose building materials are "the teachings of the Qur'an, the sayings of Muhammad, and the stories of the prophets and saints of the past" (ibid.) along with, according to Nicholson, "the history of religion, morals, and culture, in fables and folklore, in divinity, philosophy, medicine, astrology, and other branches of medieval learning, in Eastern poetry and life and manners and human nature" (qtd in Avery, 2003, p.874). In this work Rumi like biblical prophets, Milton, and Romantic poets such as Blake, and Wordsworth assumes the role of a bard or grand Sufi endeavoring to show both the common and elite where the right path is and how to avoid various traps and satanic ambushes on their path towards God, as well as how to deliver themselves when they are spiritually dried to the core. This article accordingly endeavors to explain the impediments of embracing God and ways of overcoming them in two selected allegories of Masnavi-ye Manavi:A Man's Search for his Lost Camel and The Struggle of Intellect with Nafs(lower instinct) like the Struggle of Majnun ${ }^{l}$ with his She-Camel.

\section{A. Rumi's Allegory}

Allegory by definition is a narrative both in verse or prose which has two levels of meanings; the first level of meaning corresponds with the second one; that is, characters, plot, and setting in the surface level match with those of the deep level. Sometimes a literary work is wholly allegorical like Orwell's Animal Farm or the allegory is injected in a part(s) of it; Rumi's allegories in Masnavi belong to the latter one. Unlike allegories common in English literature, Rumi's allegories do not closely conform to the definition of the allegory because he throughout his allegories briefly mentions the lesson he is going to bring home to his audience at their ends. In fact, his allegories more like parable rather than allegory in the strict sense. However, his allegories are vague, and demands further study so that their deep significance can gradually unravel itself.

\section{B. Plot Summary of Man's Search for His Lost Camel}

This allegory tells the story of the man who lost his camel when their camel caravan halted on the outskirts of the city to refresh themselves. It was night and the caravan was due to depart. Much to his consternation, he failed to find his camel nearby, and this agitated him a lot. Leaving his cargo behind, he set out to look for his camel in the city. Wishing to find the camel soon, he promised to give a good reward for anyone who gave the correct address or the clue of his camel. During seeking his camel in the streets, he met some people who poked fun at him by offering him false clues

\footnotetext{
${ }^{1}$. Legendry lover in Classic Persian and Arabic Literature who is well-known for loving Leili, his beloved.
} 
just to get the much coveted prize. Knowing his camel well, he did not get deceived by their wrong clues; and their fabricated signs did not frustrate and deter him from following his camel with stamina. While the man was searching for his camel, a young man saw him and was deeply impressed by the man's burning desire to find his camel; therefore, he decided to imitate him and pretended that he also lost his camel; during his search the young man blindly copied the man's deeds and speech, but his vain search paid off and he saw a camel which reminded him of his own camel that in the dim past had been lost. In close inspection it dawned on him that the camel was really his. He was negligent in searching it due to the hustle and bustle of life. After that event, he stopped aping the man, and instead started pursuing his own. When the original camel loser asked why he left him at last, he replied that at the beginning his quest was just for mimicry but by accompanying him, he truly found his own camel, so he was sincerely grateful for his help.

C. Plot Summary of the Struggle of Intellect with Nafs (Lower Instinct) Like the Struggle of Majnun with His She-camel.

The allegory relates the tale of Majnun, a passionate lover, who likes to visit Leili, his dearly beloved, living far from him. The best transport medium for him to pass the desert and court her is his she-camel. To reach his destination faster, Majnun keeps his camel's foal at home thinking that her foal will prolong his trip by causing problem for its mother. In the middle of desert while riding his camel, he becomes utterly absorbed in the sweet thought of Leili; he gets oblivious of the fact that where his camel is taking him. Majnun's daydreaming provides an ideal opportunity for the camel to head towards her foal back at home. When Majnun comes out from his trance like state, he realizes that he is at home once more, and this event became repeated many times. At the end, Majnun resolves not to ride the camel, and leaves it at home near to her foal. He in place of riding the camel undertakes his journey on foot.

\section{RESULTS AND ANALYSIS}

\section{A. Impediments of Reaching God and Ways of Overcoming It in a Man's Search for His Lost Camel}

Like Christian, the protagonist of John Bunyan's The Pilgrim's Progress, the real camel loser in this allegory encounters two important obstacles on his path: materialism and false religious sects. He according to Zamani (2013) "stands for the true seeker of truth [mystic] and his camel for Ultimate Truth [or God]" (p.714). The first impediment which challenges his spiritual mettle is the love of the precious objects which were gained with sweat of his brow. When the caravan symbolizing the gravitational attractions of business was preparing to set out for its destination in the middle of night, the loser suddenly realizes that his camel is lost and his cargo was left on the ground unattended, the whole world got dark for him and felt depressed. In this situation, he could rent another camel and put his merchandize over it and set forth with the caravan into his homeland, but in a maverick reaction, he forwent the prospect of gaining a substantial profit by dint of selling off his goods in the markets. More strange is his committing himself to search his camel. Attar (1142?-1220), in his Conference of the Birds delineates seven stages for any mystic bent of reaching God; the first phase is passing from the valley of Seeking (Talab in Persian). In this point the mystic "must renounce all earthly things and detach himself from all that exists" (Smith, 1932, p.29) and the camel loser like Attar's ideal mystic bravely cut himself from the fetters and allurements of the world dominated by making much lucre which was represented by his forsaking the caravan,

The caravan is ready to move on; They have all packed up, but your camel's gone-With parched lips you are searching left and right The caravan sets off, and soon it's night. Your things have just been left there on the ground, While in your search you have been wandering round (Masnavi II, 2923-2925)

Lines above vividly demonstrates that his momentous decision does not come about without any vacillation because leaving caravan with its strong pull can entice him into stooping in front of business life and hold him from commencing his journey into the new realm. The mystic with his entire surrendering to God and choosing the right path breaks down the first barrier.

Another significant hurdle for the mystic is the warring religious groups. Making every endeavor to find his camel in the short period of time, he offers a prize for anyone imparts him accurate information about his missing camel. He chances upon a group and inquires them about his vanished camel; they claim that they have seen his camel while their main intentions were receiving the 'generous compensation,'

'We saw a camel head that way, A reddish camel, searching for some hay.' One asks, 'Was it crop-eared and quite perplexed?' 'Its saddle was embroidered,' claims the next. Another asks, 'Did it have just one eye?' The next, 'Was it sick and about to die?' Each wretch in hope of a reward from you Presents to you his fabricated clue (2930-2933)

These people represent the jarring religious sects that pretend that they can lead the mystic towards God if he follows their instructions properly and comply with their defined rules. In truth, they are ferocious and voracious wolves in the cloak of very benevolent spiritual leaders who with their misleading teachings abuse the sincere religious sentiments of the multitude solely to ensure their own comfort and affluence regardless of the ordinary people's deviation from the right path and their consequent confusion. Hafiz, $14^{\text {th }}$ century famous Persian poet, in one of his ghazals acknowledges the existence of these warring groups in Islam and wanting his readers to forgive them, Let's forgive the seventy-two sects for their ridiculous Wars and misbehaviors. Because they couldn't accept The path of truth, they took the road of moonshine (qtd. in Lewisohn, p.187, 2010)

On the contrary, Rumi is relentless in exposing their evil intentions and menaces they pose to the mystic with honest heart. To draw an analogy, these groups are similar to Mr. Talkative in The Pilgrim's Progress who "say and do 
not...He talketh of prayer, of repentance, of faith, and of new birth...He is saint abroad and devil at home" (Bunyan, 1917, p.64). John Milton in Paradise Lost clearly illustrates the intention, manner, and approach of these sects,

...Grievous wolves, Who all the sacred mysteries of Heaven To their own vile shall return Of lucre and ambitions and traditions taint, ...though feigning still to act By spiritual; to themselves appropriating The Spirit of God, promised alike and given To all believers; and, from that pretense, Spiritual laws by carnal power shall force On every conscience, (VII, 508-522).

The mystic overcomes the problem by ignoring their fake gospels and keeping on his quest of the Divinity indefatigably without being contaminated by poisonous wine (falsehood) which they offer as healing sherbet (truth) on his thorny path. Since he knows the taste of divine wine well, he abhors the stench of their wine, and hence he is longing just to drink the heavenly one; that is why he is deaf to their clamor and clanging.

In the same allegory, there is another character whose impediment is being stuck in a spiritual quagmire from which he comes out. He is from the same city where the real camel loser is looking for his lost object. The strange conduct and gusto of the seeker wields overwhelming influence on his will power and awakens his longing though in the wrong way: he resolves to follow him and copy whatever he does and utters out of coveting his camel and jesting,

A man who hasn't lost a camel now Competes with you in searching anyhow; He'll claim, 'I've lost a camel, everyone!

I'll give a big reward for her return.' To share your camel is this mimic's aim; Because he covets yours, he plays this game. From false clues he can't tell a truthful clue, But, for this mimic, your words serve as cue:

If you declare, 'That clue's false!' you will see Him do the same, but it's just mimicry. And if a man gives clues you think are true (Masnavi II, 2981-2986).

The main impediment of this pretender in striving towards Him is his purposelessness which disappears by epiphanyhe experiences in the middle of the way. At the outset of his spiritual voyage, he is not unlike Stephen in James Joyce's A Portrait of the Artist as a Youngman who is unclear about his ultimate destiny. He is in limbo until the moment of his secular epiphany. His epiphany occurs when he eyes the beautiful sea-bird on the waves, at that time he clearly perceives that his mission is, "[to be the]priest of the eternal imagination" (Joyce, 2oo4, p.196)and to devote himself for creating beauty. Likewise, the pretender experiences his own epiphany when he sees a camel which evokes the vague memory of his lost camel in dim past, "He [pretender] first recalls her [camel] when he sees her, / then He covets no more those of other men" (3007-3008). After detecting his own camel, he stops mimicking and begins searching his own camel separately because he finds raison d'être for his meaningless quest. Explaining the symbolic significance of the characters, Karimi notes that " the camel symbolizes the secret of Truth [God] and the pretender represents the disciple of the mysticism who does not understand the importance of mysticism and just mimics its superficial aspect and the real camel loser is the symbol for a mystic leader" ( vol. 2, 2012, p.729), thus throughout his journey the immature and aimless disciple spiritually grows and his search becomes purposeful on the account of sudden remembrance of God. Rumi implies that his epiphany stems from accompaniment of the true mystical leader and searching God. In other words these two factors work as alchemy for the novice mystic, and transform him into real mystic who finally attains his goal: God. Commenting on the role of leader in Rumi's Masnavi, Iqbal (1991)says that "the hands of guide is the hand of God" (p.181). The leader performs constructive role in purifying his soul and purging his dishonesty "whenever dishonesty accompanies honesty, dishonesty becomes honesty suddenly [if the dishonest himself has capacity]" (Masnavi, II 2993). Regarding the importance of the quest in approaching God, Rumi praises the dynamicity and the remarkable power of quest but he has"utter opposition to quietism, withdrawal, and escape" (Iqbal, 1991, p.225). It is evident that if the disciple of mysticism was passive, never can he achieve his end because quest in Masnavi holds the key to success,

This search is a killer of obstacles on the way to God.

This search is the key to the things sought by thee, this (search) is Thy army and the victory of the banners.

This search is like chanticleer crowing and proclaiming the dawn is at hand (qtd. in Iqbal, p.227).

\section{B. Impediments of Reaching God and Their Solutions in the Struggle of Intellect with Nafs (Lower Instinct) Like the Struggle of Majnun with His She-camel}

Sufis, according to Emerick (2008) "have generally likened the quest of Majnun or crazy one as a metaphor for the imperfect human search for God" (p.50); thus, Majnun stands both for intellect and a person who is strongly desirous to reach God symbolized with Leili; nevertheless, the path leading to Beloved is not smooth and well-trodden; it is fraught with difficulties. One of them is nafs or soul represented with a stubborn she-camel trying just to join her foal which is emblem of lust in this allegory. Nafs is an ambiguous word, and needs to be elucidated in the context of Islam owing to the fact Rumi heavily draws on the teachings of Islam and Qur'an. Muslim scholars divided nafs into three types "nafs ammara, which incites to evil, ...lawwama, blaming soul... and nafs mutma'inna, the soul at peace (Schimmel, 1992, P. 256).Rumi in this allegory by nafs he means nafs ammara which is adamant that sensual needs have to be fulfilled; this nafs is an implacable enemy of spirituality. In Freudian psychology the nafs in question acts like id. Schimmel (1975) in her book entitled, Mystical Dimension of Islam beautifully summaries it,

The lower self, the base instincts, what we might render in the biblical sense as "the flesh." The faithful had been admonished in the Koran (Sura 79:40) to "fear the place of his Lord and hinder the nafs from lust." For the nafs is the 
cause of blameworthy actions, sins, and base qualities; and the struggle with it has been called by the Sufis "the greater Holy War"(p.122).

Considering the symbolic meaning of the she-camel and its foal in the allegory, Zamani (2012) asserts that "the camel stands for nafs ammara and the foal for lust; the nafs ammara constantly wants to satisfy its carnal desires and fights with intellect" (IV, p. 252). It should be mentioned that intellect in the allegory does not mean cold analytical mind but it means gnosis or superego, to borrow Freud, and one of its main responsibilities is to remain vigilant in order to curb nafs ammara's refractoriness, otherwise it does not hesitate in destroying the purity of the soul and pushing the innocent soul to the mire of horrible sins; similarly the destructive power of flesh which is equivalent of the nafs ammara is referred in Bible, "What human nature [flesh] does is plain. It shows itself in immoral, filthy, and indecent actions" (Galatians, V, 16).The struggle between intellect and the nafs ammara is ongoing and both unwilling to surrender. In the battlefield, so many times the nafs ammara is victorious especially when Majnun/intellect gets absorbed in the sweet thought of Leili/God, and becomes heedless of the aim of his quest or journey. Rumi illustrates the victory of nafs with Majnun's loosening the rein of the camel/ Nafsand the camel's immediate trip back to the foal/lust,

But the she-camel was very regardful and alert: whenever she saw her toggle slack She would at once perceive that he had become heedless and dazed, and would turn her face back to the foal without delay. When he came to himself again, he would see on the spot that she had gone back many leagues (Masnavi IV, 1538-1540)

This type of negligence in Sufism is called Ghaflat, sleep of heedlessness, which is regarded as one of the serious dangers threatening the integrity of the seeker of truth like Majnun in the allegory. Ghaflat befalls when the seeker" [in his] constant watching over one's actions and thoughts... the adept [Sufi or wayfarer] may neglect, for a moment, hisspiritual duties (ghaftat), that he may become entranced by the sleep of heedlessness" (Schimmel, 1975, 107). The victory of the Nafs proves impermanent as Majnun comes to his senses and resumes his journey to his Beloved; nevertheless, his resumption of his trip is not enough because the state of heedlessness or Ghaflat ensnares him again and again and his intellect is too vulnerable to be resistant against the ruses of the Nafs. To remove the hurdle, Majnun like the heroes of epics has to do an extra ordinary deed to rescue himself from this vicious circle in which he is stuck and accomplish his long and arduous journey. To do so, he throws himself down from the camel and injures his foot and walks on foot towards Leili,

He threw himself headlong from the camel. He said, "I am consumed with grief: how long, how long?" The wide desert became narrow for him:

He flung himself on the stony place. He flung himself down so violently That the body of that courageous man was cracked. When he flung himself to the ground thus, At that moment also by destiny his leg broke (Masnavi IV, 15511555)

To interpret it symbolically, the intellect at the end comes to this realization that the only way to draw closer to God is repressing and taming the evil nafs which nourishes lust and not permitting it to accompany him anymore in his journey. In addition, his broken leg indicates that taming the nafs is not without price and one has to suffer a lot to reunion with his Beloved. By controlling his nafs ammara, he/intellect brings the nafs Mutmainna to the fore and allows it to govern him. This nafs is capable of taking Majnun to God because God Himself calls and invites it to His garden, "But ah! Thou soul at peace-nafs mutma'inna, Return unto thy Lord, content in His pleasure! Enter thou among my bondsmen! Enter thou my garden! (Koran, 89, 27-30).

\section{DISCUSSION AND CONCLUSION}

As a poet and mystic par excellence, Rumi has a special liking for employing symbols throughout his Masnavi because they enable him to clarify the complicated mystical and philosophical issues in a manner that is both delightful and undemanding to follow. Human beings spiritual yearning for God motivates him to embark on spiritual journey to get the gates of eternal homeland; all the same, the journey is replete with spiritual entanglements, and the mystic has to surmount them if he is tenacious to reach God. Rumi clearly displays the stumbling blocks which a seeker of Truth generally encounters when he is moving towards divine destination, as well as ways of their overcoming in two allegories in his Masnavi: A Man's Search for his Lost Camel and The Struggle of Intellect with Nafs (lower instinct) like the Struggle of Majnun with his She-Camel. In the former allegory, two main impediments harassing the wayfarer are materialism and jarring religious sects. The first step for wayfarer to attain the goal of his longing is to throw off the all shackles of greediness, and the mystic in the allegory accomplishes it by abandoning the trade caravan and his precious merchandise. The second barrier is the warring sects who are attempting to deviate the pure heart seeker with their deceptive teaching from the right path of Truth whom Shakespeare vividly portrays,

Dove-feather'd raven! wolvish-ravening lamb!

Despised substance of divinest show!

Just opposite to what thou justly seem'st, A damned saint, an honourable villain! (Act III, Scene II, lines 78-81)

Since he can distinguish the wolf from lamb and Divine from Satan, he disregards their insincere teachings, accordingly their efforts to mislead him proves utterly futile.

In the same allegory, the disciple of mysticism who just blindly follows his mystical leader is imprisoned in the dungeon of his aimlessness who gets released through an epiphany resulting from his quest and keeping the company of 
a spiritual sage. Rumi places emphasis on being dynamic and one form of it is searching (Truth)though it is in vain, "The Friend [God] loves this agitation:/it is better to struggle vainly than to lie still" (Masnavi I, 1819) because he believes that it will end in success. How could the novice mystic imbibe the wine of reunion from the cup of Friend if he did not get succor from his master?

Choose a Pir [mystical leader], for without a Pir this journey is exceeding full of woe and affright and danger. Without an escort you are bewildered on a road you have travelled many times Do not, then, travel alone on a Way that you have not seen at all, do not turn your head away from the Guide (Masnavi I, 2943-2945)

In latter allegory, Rumi uses camel symbolism for the dark force of soul, nafs ammara, which works as a spiritual road block for the wayfarer because it guides to the wrong address "Be not a friend to temptation and desire,since it leads you astray from the Way of God" (Masnavi I, 2957) and the best way to conquer this road block is to act against it In an allegory similar to the allegory under inspection liken the nafs ammara to ass (camel), and lust to fodder (foal),

Beware! Do not let your ass go, and do not remove your hand from him, Because his love is for the place where green herbs are plentiful. If you carelessly leave him free for one moment, He will go leagues in the direction of the herbage. The ass is an enemy to the Way, madly in love with fodder:

Oh, many is the attendant on him that he has brought to ruin!

If you know not the Way, whatever the ass desires, do the opposite:

That, surely, will be the right Way.

"Consult them, and then oppose:

He that disobeys them not will be ruined."

Be not a friend to temptation and desire, Since it leads you astray from the Way of God (Masnavi I, 2952-2957)

With obeying the commands of Intellect, the seeker resists the strong urges of the nafs ammara,and grants permission to the nafs mutma'inna to be his absolute sovereign; the fruit of such a new kingship is enormous pleasure of God and His cordial invitation to "[His] Garden of resort and [his] vision..." (Masnavi VI, 334).

To conclude, according to Rumi in these allegories main hurdles on the path of an honest seeker are materialism, the false religious groups, aimlessness, nafs ammara, and lust and their solutions lie questing, in having a spiritual leader, renouncing greediness and lust, as well as following Intellect.

\section{REFERENCES}

[1] Abrams, M. H. (Ed.). (1987). The Norton Anthology of English Literature: The Major Authors (Vol. I). New York: Norton \& Company.

[2] Avery, P. (2003). Rumi. In S. T. Pendergast (Ed.), Reference Guide to World Literature. Farmington Hills: Saint James.

[3] Bunyan, J. (1917). The Pilgrims's Progress. Boston: Athenaeum Press.

[4] Emerick, Y. (2008). The Complete Idiot's Guide to Rumi Meditations. New York: Penguin Group.

[5] Good News Bible. (2004). Uk: Bible Socities/Collins.

[6] Iqbal, A. (1991). The Life and Work of Jalaluddin Rumi. Islamabad: Pakistan National Council of Arts.

[7] Joyce, J. (2004). A Portrait of the Artist as Young Man and Dubliners. New York: Barnes \& Noble Classics.

[8] Lewisohn, L. (Ed.). (2010). Hafiz and the Religion of Love in Classical Persian Poetry. New York: I.B. Tauris \& Co Ltd.

[9] The Glorious Quran. (2003). (M. M. Pickthall, Trans.) New York: Tahrike Tarsile Quran,Ink.

[10] Rumi, J. A. (13th Cen). Masanvie-Manavi Volume I. (R. Nicholson, Trans.) PDF Retrieve from www.sufism.org on March third, 2014.

[11] Rumi, J. A. (13th Cen). Masnavi e Manavi Volume VI. (R. Nickolson, Trans.) PDF Retrieved from www.sufism.org on March third, 2014.

[12] Rumi, J. A. (2007). The Masnavi Book Two (or Volume II). (J. Mojaddedi, Trans.) Oxford: Oxford University Press.

[13] Schimmel, A. (1992). A Two-Colored Brocade: The Imagery of Persian Poetry. Chapel Hill: The University of North Carolina Press.

[14] Schimmel, A. (1975). Mystical Dimentions of Islam. Chapel Hill: The University of North Carolina Press.

[15] Shakespeare, W. (2002). Romeo and Juliet. New York: Barron's Educatin Series, Inc.

[16] Smith, M. (1932). Wisdom of East: The Persian Mystics Attar. New York: E.P. Dutton and Company INC

[17] Zamani, K. (2012). A Comprehensive Comentary of Mathnavi e Manavi (Vol. IV). Tehran: Etelaat.

[18] Zamani, K. (2012). A Comprehensive Commentary of Mathnavi e Manavi (Vol. II). Tehran: Etelaat Pree.

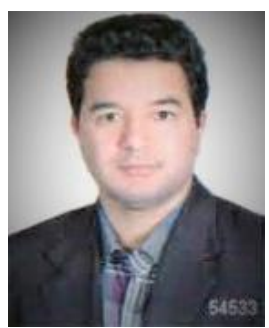

Ahmad Gholi was born in Kalaleh, Iran in 1984. He received his M.A. degree in English literature from Lorestan University, Iran in 2007.

$\mathrm{He}$ is currently a lecturer in the Gonbad Kavous University, Golestan, Iran. His research interests include Persian Literature, Travel writing and English literature. 


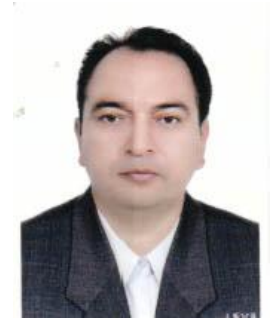

Masoud Ahmadi Mosaabad was born in Gonbad, Iran in 1984. He received his Ph.D. 2002 in degree in English literature from Pune University, India in 2002. He is currently an assistant professor in the Gonbad Kavous University, Golestan, Iran. His research interests include American literature, English Literature, and Turkmen Literature. 